Historic, Archive Document

Do not assume content reflects current scientific knowledge, policies, or practices. 


\section{COKER'S PEDIGREED ABRUZZI RYE AND RED OATS}

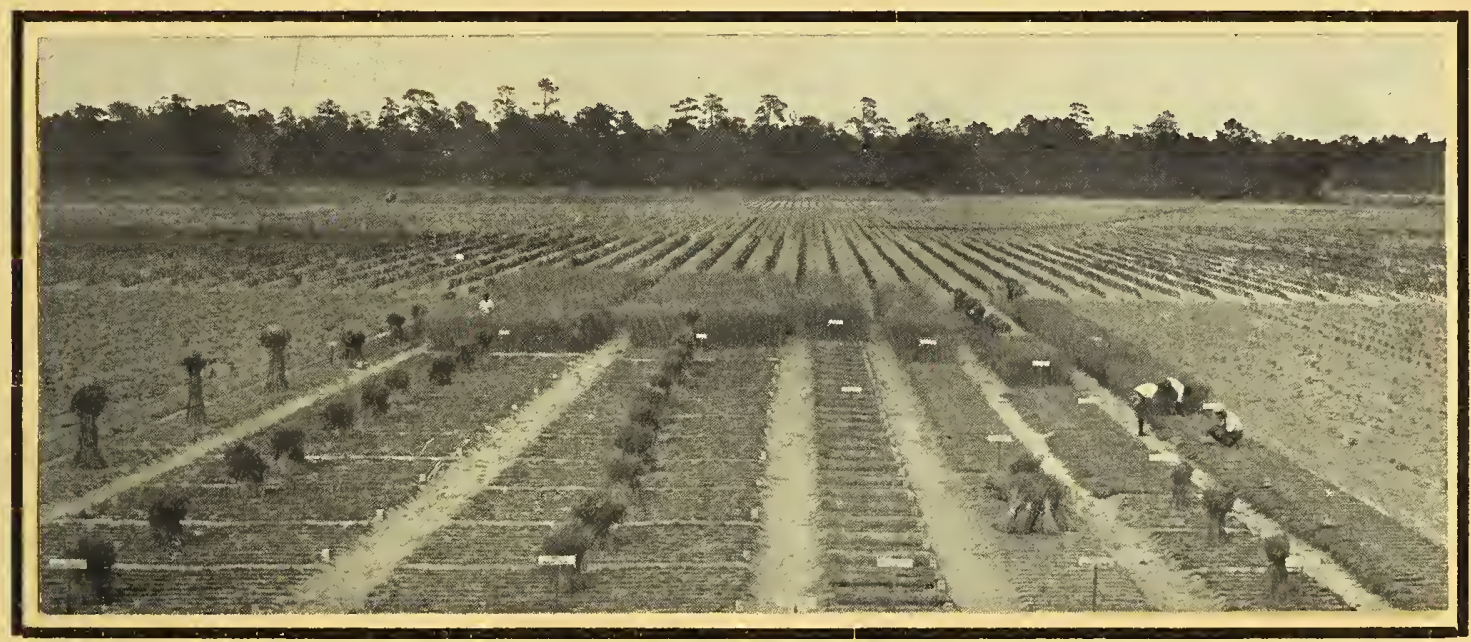

Breeding Plots of Rye and Oats on Pedigreed Seed Farms, Hartsville, S. C.

PEDIGREED SEED COMPANY 11 OPERATING THE PEDIGREED SEED FARMS 


\section{What Our Customers Say}

PEDIGREED SEED FARMS

Hartsville, S. C.

Dear Sirs:-Your selected Oats (Coker's Pedigreed) yielded at the rate of ninety-two bushels per acre, as compared with about eighty bushels of the best quality Appler Oats. The yield of the Abruzzi (Coker's Pedigreed) Rye we obtained from you was far better than any other variety. It was much earlier and more hearty, and yielded more grain. This was true on our College Farm here, on our Experiment Station, at our Pee Dee Station located at Florence, and at our Coast Station located at Summerville. The superiority of the Abruzzi Rye and your Oats is quite marked, and I am more than pleased to write you this letter.

$$
\begin{aligned}
& \text { J. N. HARPER } \\
& \text { Director Clemson College Agricultural } \\
& \text { Experiment Station } \\
& \text { Clemson College, S. C. }
\end{aligned}
$$

PEDIGREED SEED FARMS

Hartsville, S. C.

Dear Sirs:- . . . I had lots of people out to see these Oats in the field, and showed them the difference in plats, as I had the other best oats I could buy, the Hastings roo-bu. Oats and the Red Appler, both favorites here, and good oats; but it was an easy matter to tell where the first row of your Oats (Coker's Pedigreed) started.

$$
\begin{aligned}
& \text { H. H. JAMES } \\
& \text { Fitzgerald, Ga. }
\end{aligned}
$$

\section{PEDIGREED SEED FARMS}

Hartsville, S. C.

Dear Sirs:-I was very much pleased with the Red Appler No. 24 Oats (Coker's Pedigreed) and the Abruzzi (Coker's Pedigreed) Rye purchased from you last fall. I expect to plant both again this fall, and feel that they are both superior to all other seed that I have seen planted. The growth of the Abruzzi Rye under adverse conditions (late planting and a dry spring) was an eye-opener to me. It opens new possibilities in the way of soil improvement that I hope the people of this State will not be slow to appreciate.

\section{J. E. MILLS}

University of South Carolina

Columbia, S. C.

\section{PEDIGREED SEED FARMS}

Hartsville, S. C.

Dear Sirs:-We had a very severe dry spell, which cut our oat and rye crops short-in places, it did not make half a crop. In spite of this, there was a marked difference in the evenness of yield of the (Coker's) Pedigreed (Red) Oats and (Coker's) Pedigreed Abruzzi Rye from other oats and rye planted alongside of these in the same field. The Abruzzi Rye was also much earlier than our other rye, showing a marked superiority for pasture and as a winter cover crop.

THOMAS F. PARKéR President Parker Land Company Greenville, S. C. 


\section{THE CASE FOR PEDIGREED SEEDS}

A pedigreed horse is one descended from individual horses of tested and recorded efficiency. Such horses are capable of transmitting their qualities from one generation to another. In a similar way, plants are able to transmit their qualities. Good plants ordinarily will transmit good qualities, and poor plants poor qualities; but, just as with animals, there are infinite variations and tendencies. The work of the stock breeder and plant breeder is to select the individuals that have desirable qualities, test them, and select them for several generations, until he has a pedigreed strain of stock or seed with a proven record for efficiency.

Although a farmer is usually extremely careful in buying only the best pure-blood live stock, yet he is extremely careless in buying seed. Usually, he goes to a flashy catalog of a flashy seedsman, and picks ot: the flashiest picture, described in the flashiest language, and thinks he is buying good seed. WE MAINTAIN THA'T IT'S TIME FOR HIM TO MAKE A CHANGE. The pedigree of his seed is of equal importance to him as the pedigree of his stock. He should know that his seed is descended from parent strains of seed that have proven their worth as individuals, and in competition with other strains and other varieties. It means dollars in his pocket. Let him plant a test plot of pedigreed and one of non-pedigreed seed side by side, and note results. We have done this for several years, and our results are that the average difference in favor of pedigreed rye over non-pedigreed rye is $53 / 4$ bushels per acre; and oats show a difference in favor of the pedigrced of nine bushels per acre.

The superior value of pedigreed seed is universally admitted by scientific agriculturists. The only question now is whether the farmers of the South will take the advantage that is offered them. Such seed as we are breeding will be worth millions of dollars to the South when generally distributed. No one in the Southern States is doing such careful and conscientious breeding work, on such a scale as we are doing it; and our pedigreed strains of seed are offered to Southern farmers with the confidence that they will greatly profit by their use.

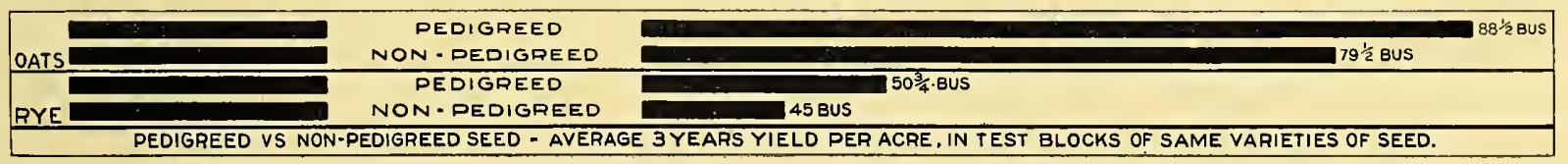




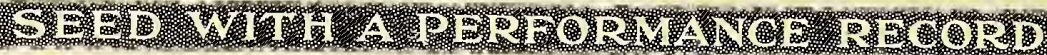

\section{OUR MEN AND OUR METHOD}

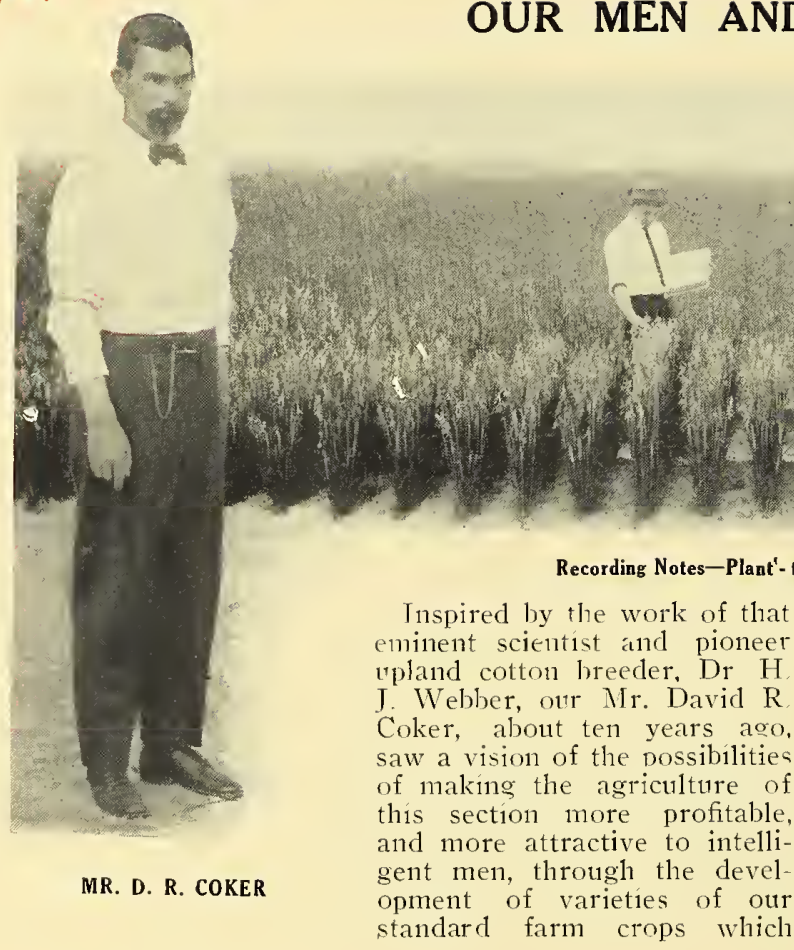

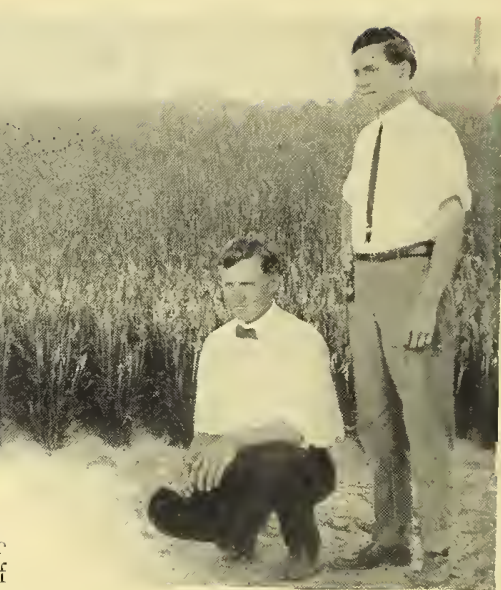

greater yields, of lietter quality and higher money value. Taking up first the pedigree breeding of cotton, he rapidly expanded this work until it now embraces the breeding of cotton, corn, oats, rye, peas, sorghum, and several other crops. In addition to the breeding work, many agricultural experiments of an everyday practical nature are planned and carried through with scientific accuracy each year, 
and the results published in bulletins and papers for distribution.

\section{OUR MEN}

From the nature of the work, pedigree plant breeding can be entrusted only to high salaried experts, men who have scientific knowledge and practical experience in the special field of plant breeding. We are fortunate in having a corps of such experts in our continuous service, men who have been with us several years.

Our Mr. David R. Coker is known over a large part of the South as an agricultural and plant breeding expert of high rank. He is also recognized as the founder and chief exponent of the new upland staple co:ton industry of the Carolinas. The Souttern Farming (editorial of March 2I) says: "The conclusions which he comes to in regard to various crops, varieties, etc., are just as accurate and dependable as those of any Experiment Station anywhere. $\mathrm{He}$ is looked upon by all who know him as one of the best and most accurate experimenters with farm crops to be found anywhere, and when he says anything he has proofs to back his statements."

Southern Culticator, May, I9I4-"We knew that he (Mr. D. R. Coker) was doing a very great work, but its fu'll import can only be realized by a personal visit."

Our Mr. S. Pressly Coker, Plant Breeder, is a graduate of Virginia Polytechnic Institute and of Cornell University Agricultural College, and is an expert in plant breeding whose achievements are well known. He has published numerous articles and addresses along agricultural lines that have gained wide circulation.

Our Mr. George Wilds, Plant Breeder, is a graduate of the University of South Carolina, and has had four years of practical training in plant breeding.

Mr. D. R. Coker devotes only a part of his time to the plant breeding business, but Messrs. S. P. Coker and Wilds devote their entire attention to it. They have numerous assistants and work hands who are constantly employed in carrying out the work of the Pedigreed Seed Farms.

\section{OUR METHOD}

THE, "PLANT-TO-ROW METHOD" in a few words means just this: testing individual plants in separate rows, as near as possible under identical conditions of soil preparation, fertilization, and cultivation ; noting all the qualities throughout the season, harvesting and threshing each row to itself, and recording the yields of each. By this method only is it possible to identify the inherent qualities of the individual plants, and to isolate those valuable high-y:elding plants which under the same conditions and in competition with other plants have proven their superiority and their ability to reproduce their high yielding qualities.

In animal breeding, the most valuable animal to the breeder is not the animal with the highest individual record, but the animal that has, coupled with that high record, the ability to produce the largest number of high record progeny. Likewise, in plant breeding, the

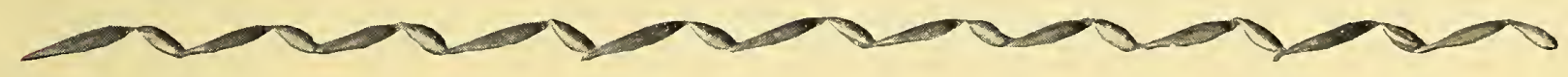


most valuable plant to the farmer is not the high yielding individual plant, but that high yielding plant which has proven its ability through its performance records in the test blocks to reproduce its high yielding quality. In plant breeding as in animal breeding we must make the individual the unit, and prove the individual plant before it is increased and offered to the public.

This method of PROVING THE INDIVIDUAL PLANT, and then increasing and testing its progeny for three years, giving it a traceable Pedigree back to the individual plant, is OUR METHOD, and we offer for sale only the seed from those plants that have proven their value for the three years, and that have a high performance record.

We are spending thousands of dollars each year (most of it in one twenty-five-acre field) in carrying on our seed breeding work. Plant breeding work has been going on upon our farms since 1902, but not until I909 did we offer Pedigreed seed to the general public.

We offer for sale the only Pedigreed Oat and Rye Seed raised in the South-Oat and Rye seed with a high performance record in the field; Oats that have for two years won the Sweepstakes prize for the entire South; Rye that has for the same period won the Grand Champion Sweepstakes prize for the world, at the Fifth and Sixth National Corn Expositions, I9I3 and I9I4.

In using our seed you have the advantage of all this high grade and expensive work we have done in bringing these seed to their high state of perfection, and you have seed that will repeat their good records under Southern conditions, and give you bigger yields and more value for the money expended.

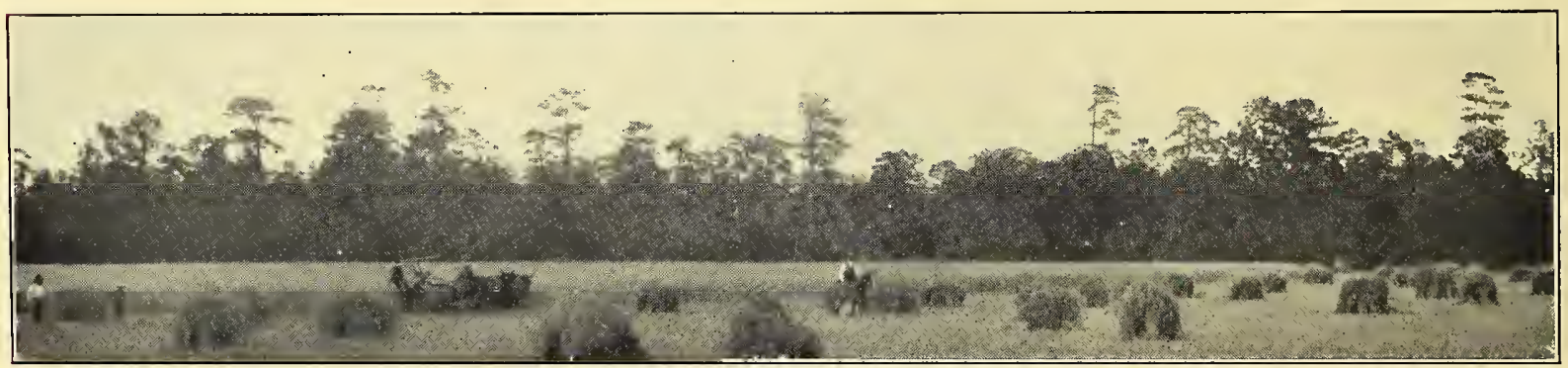

Harvesting a Field of Coker's Pedigreed Abruzzi Rye 


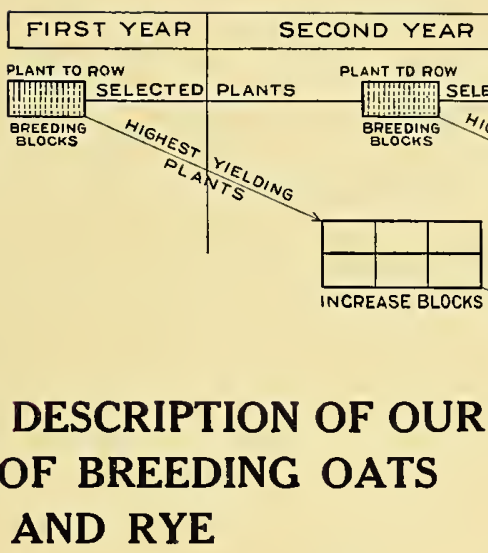

VALUABLE PLANTS THAT HAVE “MADE GOOD” IN THE BREEDING BLOCKS

are propagated in the "Increase Blocks" for further testing, and for increasing the amount of seed for use in the general fields. Strains that make the best yields for three years in the Breeding and Increase Blocks and the variety tests, are planted in the general fields the fourth year, and the resulting "Pedigreed Seed" are offered to the public. This process is continued year

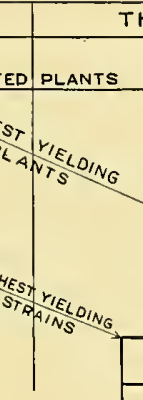

THIRD YEAR

PLANT TO ROW

III:THELECTEO PLANTS

FOURTH YEAR

PLANT TO ROW

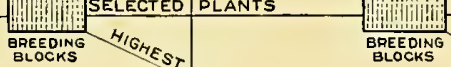

BREEDING
BLOCKS
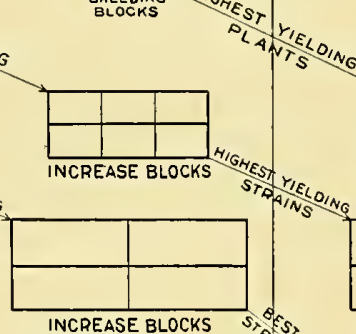

after year. We test and prove the individual plant and strain, and then increase the strain without mixture. Each of our strains has a pure and traceable pedigree, the records of which we keep year after year. It is only by this pedigree method that absolutely certain breeding results may be obtained. 


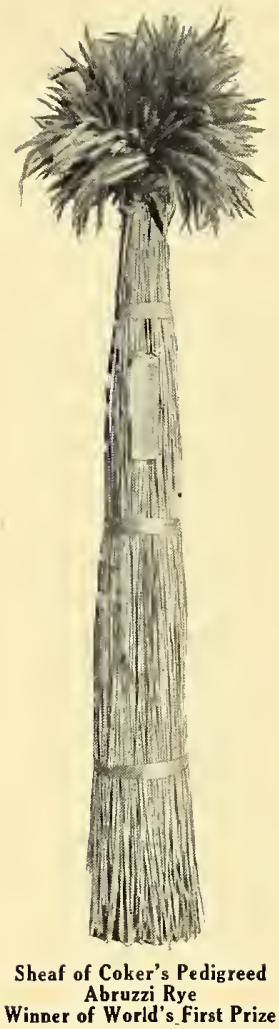

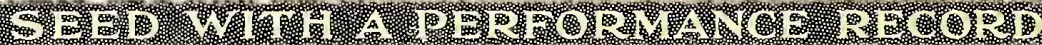

\section{COKER'S PEDIGREED ABRUZZI RYE}

\section{ITS HISTORY}

Abruzzi or Italian Rye was discovered by agents of the United States Department of Agriculture, while on an exploration trip through Italy in search of valuable plants for use in this country, and was introduced for the first time about January, rgoo. It canne from Naples, and brought with it this record: "Abruzzes, a superior rye grown in the Abruzzi Province, a mountainous district east of Rome. This strain is one of the best grown in Italy, having made an average yield of 28.2 bushels per acre for a period of ten years."

This rye was tested by the United States Department of Agriculture, found to be valuable, and was distributed about 1906 or 1907 , but for some reason it seems to have been lost sight of until improved and in roduced azain as "Coker's Pedigreed" Abruzzi Rye in the fall of I9I3.

\section{ITS PEDIGREE}

Coker's Pcdigreed Abruz $R$ i $R$ is descended from two plants which were selected from a field of this general Abruzzi rye in the spring of 19a9, and tested alongside of many other selected plants of the same variety. These two plants indicated their good qualities by the high average yield of 67.2 btishels per acre in I9IO, and in I9II, I9I3, and I9I4 the progeny made an average yield of 56.6 bushels per acre, as against 45.2 bushels for the general Abruzzi, showing a better record by 11.4 busl:els per acre than the parent strain. These high yields were of course made under test plot conditions. We make, under average farm conditions, from twenty to thirty bushels per acre of this rye on a large acreage. 


\section{ITS USES AND ADVANTAGES}

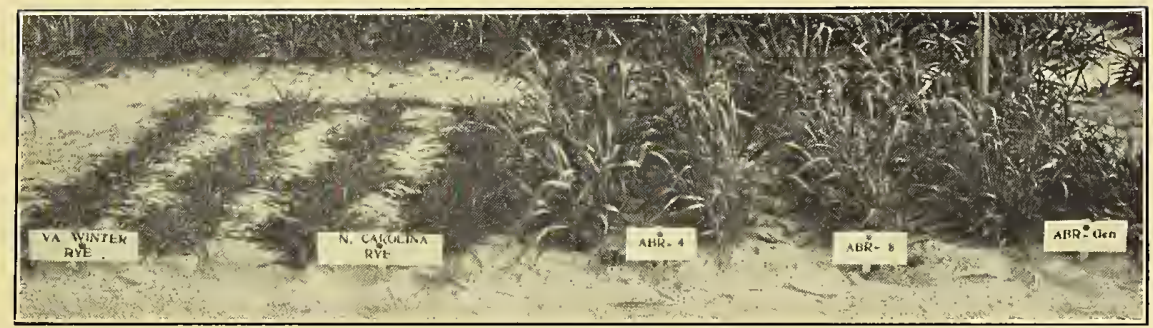

Rye Varieties, Showing Superiority of Ahruzzi-Photographed March 1

\section{AS A WINTER COVER CROP}

A cover crop, to be of much value, must make a heavy growth of vegetable matter during the Fall and Winter, when the land is idle; and the fact that Abruzzi Rye makes such a tremendous growth early, makes it the best Winter cover crop for the South that we know of.

Vetches, Clovers, and other leguminous crops have been recommended, but the fact is these crops do not make sufficient winter growth to be of much value to the average cotton farmer, who has to begin plowing not later than February if he is to plant his crop on time.

An experiment to determine the yield and value of different cover crops planted October 15, I9I3, and gathered February II, I9I4, gave approximately the following results:

Hairy Vetch I ton per acre
Virginia Winter Rye ............. 2 tons per acre

Coker's Pedigreed Abruzzi Rye + tons per acre

This shows the superiority of Abruzzi Rye over all other crops tested.

\section{AS A WINTER GRAZING CROP}

Abruzzi Rye is far superior to the ordinary rye varieties. In carefully conducted tests, we find that it will give from two to three times the amount of pasturage or forage that our ordinary varieties will.

In addition to its heavy yield, it possesses the distinct advantage of growing upright, making it easv for the animals to graze. It does not lie flat on the ground the animals to graze. It grows off upright from the very start.

WE DO NOT KNOW OF ANY CROP THAT WILL, GIVE AS MUCH GRAZING DURING THE WINTER AS ABRUZZI RYE. 


\section{A HEAVY SEED PRODUCER}

The superiority of Abruzzi Rye in seed production is very marked. We find no difficulty in raising from twenty to thirty bushels per acre, on fairly good soil. For the past two years we have made an average yield

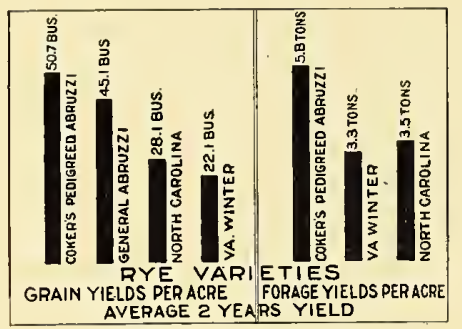

of twenty-six bushels per acre on our Hartsville plantation, and when we compare this yield with the average ten-year yield of II.3 bushels per acre for our ordinary ryes in the Southern States we can readily see the superiority of the Abruzzi Rye. In our test blocks, as shown in an accompanying table, we usually raise two to three times as much grain from Abruzzi Rye as from our native ryes.

\section{TIME AND METHOD OF SEEDING COKER'S PEDIGREED ABRUZZI RYE}

FOR COVER CROP AND GRAZING PURPOSES, we find that Abruzzi Rye should be sown from September 15 to October I5, for best results. If sown earlier than September 15, the young plants are very apt to be killed by the hot sun, and if sown much later than October 15 the plants will not have sufficient time to make their best cover crop growth before time to turn them under. We recommend planting in cotton fields after the first or second picking, about September I5. $_{5}$ Sow the rye broadcast between the rows, and turn under with a large sweep, one furrow to the row. We find this method very satisfactory; and the cotton is not injured in any way. For seeding after hay, it should be sown as soon as the hay is harvested, and may be sown broadcast and harrowed in, or seeded with a regular grain drill as suits best.

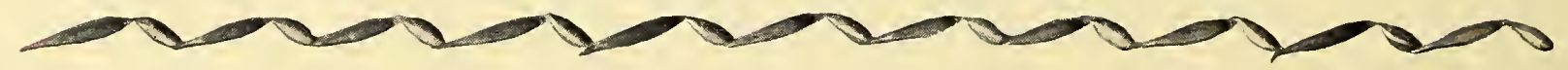


FOR SEED PURPOSES, we recommend seeding with a grain drill, from the first to the fifteenth of November in the upper half of the cotton belt, and two weeks later in the lower half. This rye is considerably earlier than our native ryes, and if planted earlier than this it will head out very early in the Spring, and may be injured by cold weather. We prefer planting here as near November I5 as possible, and advise a strict adherence to the above rule for best results.

We give out this information after much careful experimenting to determine these points, and we feel sure that those who follow directions will reap the best results.

\section{RATE OF SEEDING}

After conducting experiments running over several years, we find that a seeding of $1 / 2$ bushel per acre on good soil, and $3 / 4$ bushel per acre on light soils, for November I5 planting, will give best results. When planted in this way, every plant will have ample oppor- tunsty to produce a large number of heavy heads, and large grains. If planted later than November i 5, however, a heavier seeding should be used, for the plants will not have time to stool properly, and bigger yields can then be obtained from heavier seedings. Very late plantings, however, will not give satisfactory results.

Of course these light seedings require a GOOD SEED BED, and we advise a thorough preparation of the land before planting. DON'T FAIL to break and harrow your land thoroughly, and use a grain drill that will plant a small amount of seed to the acre.

\section{PRICES}

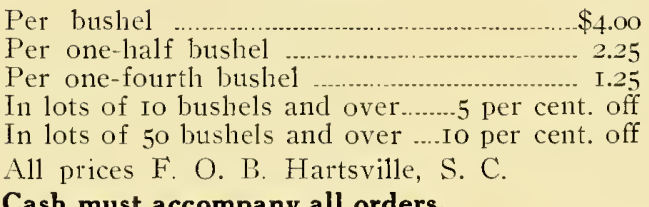

Cash must accompany all orders.

Practically all orders shipped the same day received.
Don't buy seed from too far North or South of yout. Seed grown and bred in the South are best for Southern planting.
We do not care to open ledger accounts for seed, and will therefore return any orders which are not accompanied with cash.

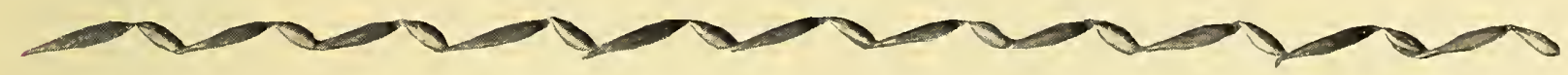




\section{PERFORMANCE RECORDS-COKER'S PEDIGREED ABRUZZI RYE}

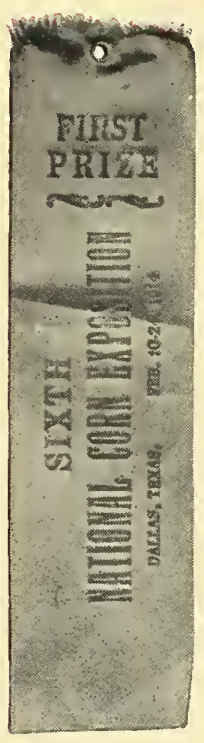

Grand Cbampion Sweepstakes Prize (World's Prize) Sheaf Coker's Pedigread Abruzzi Rye
FIFTH NATIONAL CORN EXPOSITION, I9I3-COLUMBIA, S. C.

Grand Champion Sweepstakes Prize, Sheaf Abruzzi Rye (world prize)

Southern Zone Sweepstakes Prize, Sheaf Abruzzi Rye

First Prize, State South Carolina, Sheaf Abruzzi Rye

First Prize, State South Carolina, Peck Abruzzi Rye

SOUTH CAROLINA STATE FAIR, IgI3

First Prize, Peck Abruzzi Rye First Prize, Sheaf Abruzzi Rye MARLBORO COUNTY FAIR, I9I3

Awarded Blue Ribbon for Excellency-No Prize Offered

SIXTH NATIONAL CORN EXPOSITION, I9I4-DALLAS, TEXAS

Grand Champion Sweepstakes Prize, Sheaf Abruzzi Rye (world prize)

Southern Zone Sweepstakes Prize, Sheaf Abruzzi Rye

These are the only fairs or shows in which we have exhibited any of our pedigreed seeds.
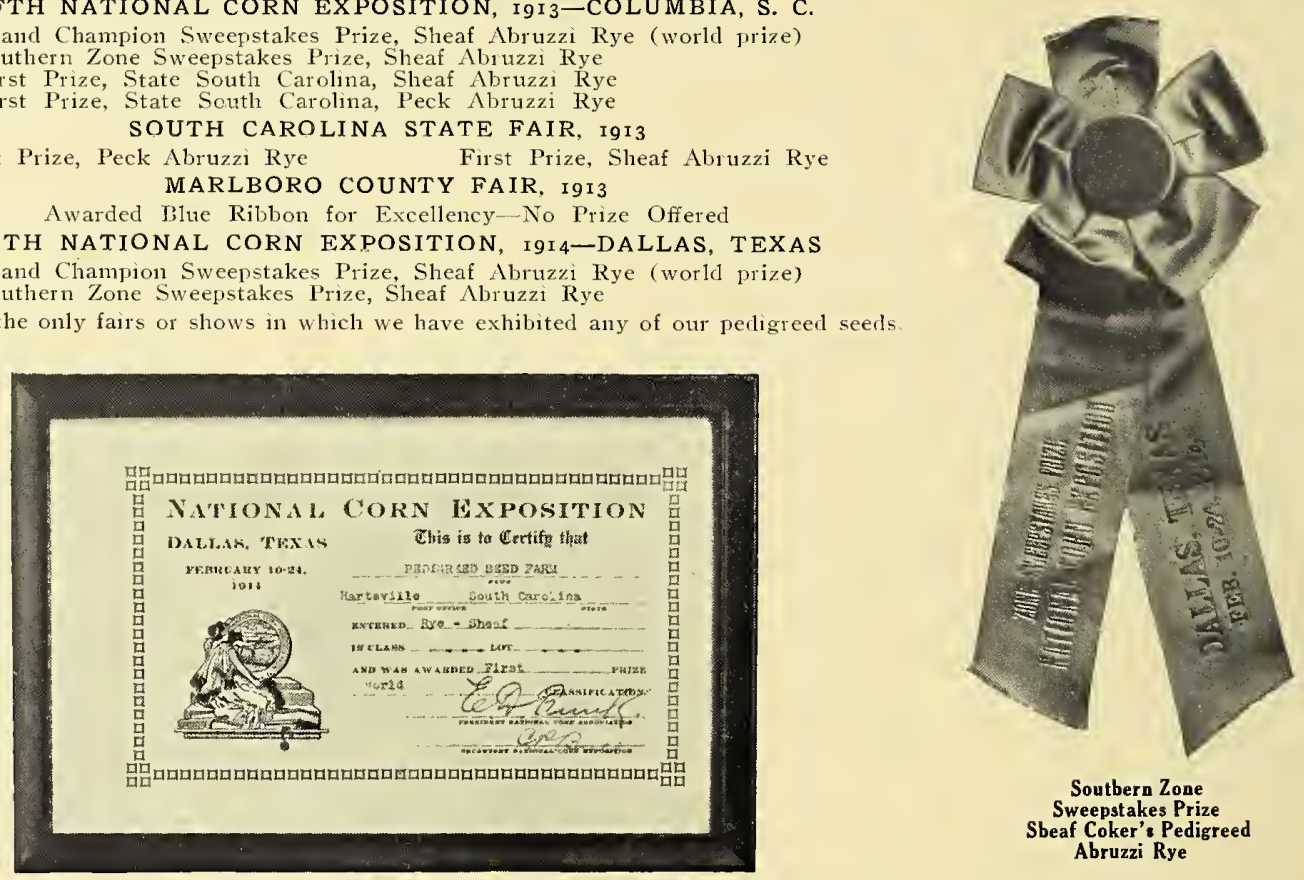

Soutbern Zone Sweepstakes Prize Sbeaf Coker's Pedigreed Abruzzi Rye

Certificate of Award-First World's Prize Sbeaf Coker's Pedigreed Abruzzi Rye 


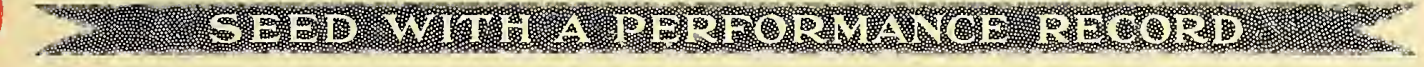

COKER'S PEDIGREED RED OATS

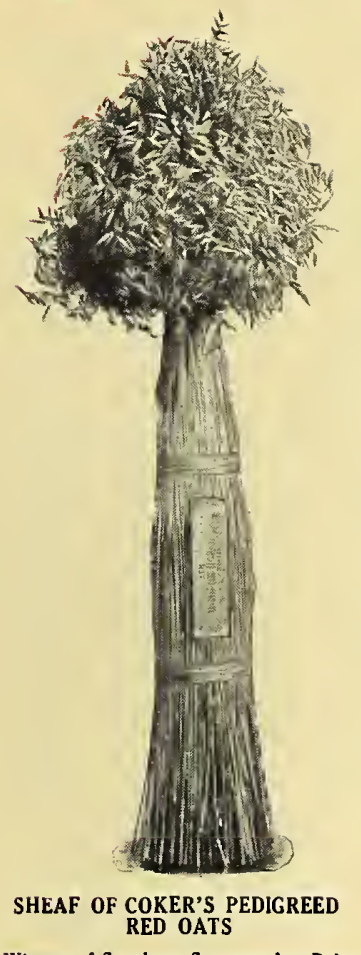

Winner of Southern Sweepstakes Priz

\section{ORIGIN AND BREEDING}

The origin of Coker's Pedigreed Red Oats goes back to a field of Red Appler Oats harvested in the Spring of I909, and the Red Appler Oat itself traces back many years to the well-known variety of Texas Red Rustproof Oats. Good heads and plants were selected for a number of years from Red Rustproof stock, and grown by a man named Appler, who introduced them as Red Appler Oats, and for many years they have been planted very generally throughout the Southern States.

The beginning of our oat breeding work goes back to the Spring of Igos, when a number of apparently productive plant selections were made from a field of Red Appler Oats for testing in our plant-to-row test of Igog. Every year since that time we have made plant selections for similar tests. and in all have tested over three hundred individual plants, the records and yields of each plant being recorded separately in our record books. Out of these three hundred plants tested, only four plants, up to the present time, have proved worthy of increasing and offering to the public.

The oats we are now offering for sale trace back to two high-yielding plant selections in our I9Io breeding plots, which for the past four years, I9II, 19I2, I9r3, and I9I4, have been increased separately, and have rroved their ability in both the test plots and general fields to reproduce their high yielding qualities.

In all our breeding work we have had as our primary object the production of high yielding, uniform strains of oats, and only those strains that combine these two qualities are offered to the public.

\section{YIELDS}

Every year we conduct Variety Tests of oats, in which we test our Pedigreed strains in comparison with other standard varieties; and we publish in the accompanying charts the results of these tests. Chart No. I gives the average yields for three years of seven different varieties and strains. Chart No, 2 gives the results of our I9I4 variety Test, which we have just completed, and which shows Coker's Pedigreed Red Oats to have made the highest yield.

While a one-year test is not conclusive, and we do not publish it as such, yet it shows in this case that Coker's Pedigreed Red Oat holds its three-year record by leading all other varieties tested against it. We publish this record because it contains tests of several varieties not included in Chart No. I, and because it furnishes a good basis for judgment as to the best varieties to plant, when con sidered in connection with Chart No. I. 


\section{CHARTS SHOWING VARIETY YIELDS}

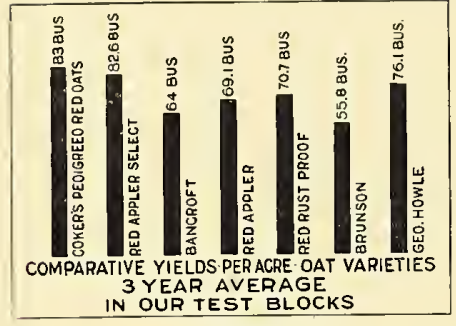

Chart No. 1

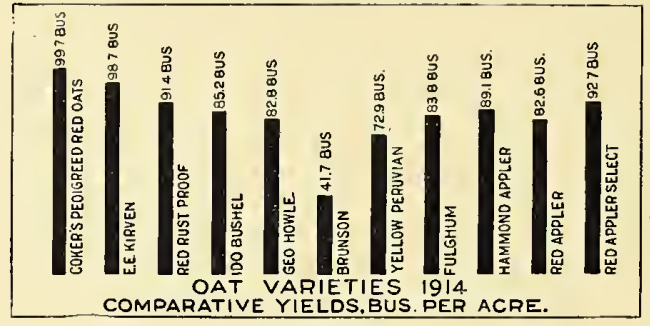

Chart No. 2

\section{TIME AND METHOD OF SEEDING OATS}

The time and method of seeding oats varies considerably in different sections of the South, and very often it varies in a particular section, depending of course upon the purpose for which the crop is intended, the variety of oats planted, weather conditions, and so on. While it is true that oats are planted for different purposes, they are best suited for grain, and are generally planted for such purpose; so in considering the time and method of planting we refer to the grain crop.

Although the time of planting does vary in any given section, there is a best average time for planting, and every farmer should try to ascertain this best time for his particular section, and try to plant as near that time as possible every year. For this section of the South, our experience seems to show that seeding from the fifteenth to the thirtieth of November will give best average results, especially when a light seeding per acre is used.

The stooling capacity of a plant is largely determined in the early part of its growth, and planting the last of November gives each plant ample opportunity to do its best and to produce its maximum number of stems. Oats planted much later do not stool near as

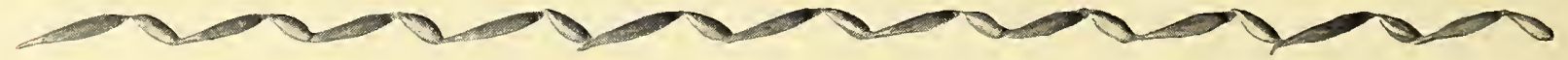


heavily, and consequently give fewer heads and smaller yields. Our recommendation as to rates of seeding of course applies only to Fall sown oats, and not to Spring oats. Practically all the oats sown in our section are sown in the fall, spring planting giving much smaller yields.

For many years, almost every farmer seeded his oats by hand, broadcast. As soon as the corn crop was gathered, his land was broken, the oats sown broadcast, and harrowed in. This method had its disadvantages; a very serious one being that often there was much winter killing. The little plants came up on the level, and had no protection from the cold winds. The method of planting with a drill is today being used on most up-to-date farms. The open furrow method is popular and effective in some sections, but is not so economical of labor and seed as the drill method. We recommend planting with a drill after the land has been thoroughly prepared, and we have never lost a crop of drill-planted oats by winter killing.

The yield of any crop is largely dependent upon the preparation of the seed bed, and especially is this true of a crop like oats or rye, which is never worked after it is planted. Good preparation means good environment for the plants, and will pay for itself many times in the quality and yield of the crop produced.

\section{RATE OF SEEDING}

The question of how much seed to sow to obtain best results is one of very great importance. It is not uncommon to find farmers who plant as much as five bushels of seed per acre, but perhaps the majority of them plant from two to three bushels per acre. If you will examine a field of oats seeded at the rate of five bushels per acre, you will at once notice that the plants are very thick. Some plants will be high, others low, showing that there is competition between the plants. If you examine the crop at harvest time you will notice that in the competition some of these plants have been choked out and are practically worthless, and that while those plants that were most vigorous have grown and matured, they have been hurt in the competition. Many of them have only one stem from a seed. There has not been room for development, and consequently the heads are small, the grains light, and the yield and quality not what it should be. If you now examine a field with a light seeding per acre, you will notice that each seed has produced a plant with a number of stems; there has been no competition between the plants; each plant has developed into its best; the stems are many, the heads are heavy, and the yield is large.

Observing this fact, we began a set of experiments to determine the best rate of seeding to use for heaviest

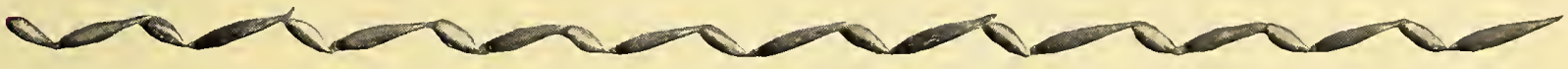


yields. These experiments began in 19I0, and were carrid out with the greatest care. All grains were placed and spaced in the test plots by hand, and everything was done with the greatest accuracy. For three years in succession the three-peck seeding gave best results, yielding an average of nine bushels per acre more than the six-peck seeding, and $3^{\mathrm{T} / 2}$ bushels per acre more than the nine-peck seeding. The fourth year, with seedings from one peck to one bushel per acre, the threepeck seeding gave a yield of nine bushels per acre more than the next heaviest yielding plot, which was seeded at the rate of two pecks per acre. Our I9I 4 tests, which are just completed, give practically the same results for the different seedings of $1 \frac{1}{2}, 3 / 4$, and $3 / 8$ bushels per acre, but on account of irregularities in the test plots these last results are not considered accurate.

We conclude, therefore, that the correct seeding per acre for good soils in this section, where drill plant- ing is used, is about three pecks per acre. Our ex periments lead 's to believe that much less seed are needed on rich land than on poor, and while we recommend a seeding of three pecks on good soil, we feel that as much as two bushels per acre may be needed on soils of a light sandy character. Of course a THIN $S E E D I N G$ requires a GOOD SEED BED, as we have already recommended.

\section{PRICE COKER'S PEDIGREED RED OATS}

I bushel $\$ 1.50$

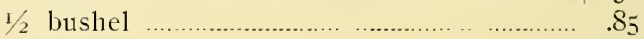

$1 / 4$ bushel ..................................................... 50

Io bushel lots and over ............... pere cent. off

50 bushel lots and over ........ Ten per cent. off

All prices F. O. B. Hartsville i. C.

\section{Cash must accompany every order.}

Practically all orders shipped the same day received.
"When each farmer in a community can be induced to conduct a few accurate experiments each year, and exchange information with his neighbors, we will see a revolution in our agriculture that will astonish the world."-D. R. CoKEk.
We do not sell Coker's Pedigreed Seeds through agents or other seedsmen. Others may advertise "Coker's Seeds," but you cannot obtain the pure pedigreed seed raised under the personal supervision of $\mathrm{Mr}$. Coker except through us.

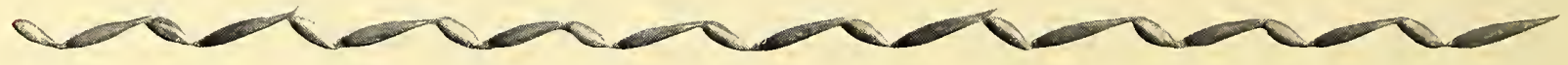




\section{PERFORMANCE RECORDS-COKER'S PEDIGREED RED OATS}

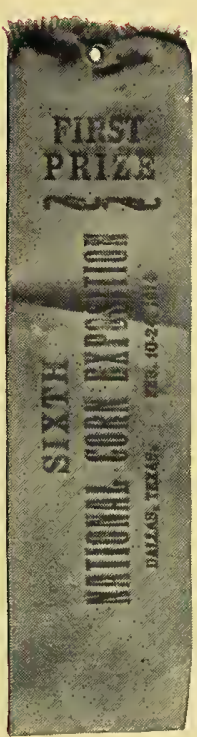

First Prize South Carolina Sheaf and Peck Coker's Pedigreed Red Oats
FIFTH NATIONAL CORN EXPOSITION, Igr3-COLUMBIA, S. C

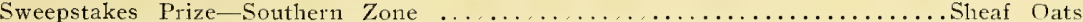

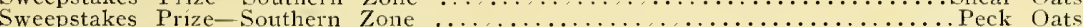
First Prize-South Carolina, Sheaf Oats $\ldots \ldots \ldots$ First Prize-South Carolina, Peck Oats SOUTH CAROLINA STATE FAIR, IgI3

First Prize-South Carolina, Sheaf Oats First Prize-South Carolina, Peck Oats MARLBORO COUNTY FAIR, I9I3

Awarded Blue Ribbon for Excellency-No Prize Offered

SIXTH NATIONAL CORN EXPOSITION, IgI4-DALLAS, TEXAS

Sweepstakes Prize-Sonthern Zone $\ldots \ldots \ldots \ldots \ldots \ldots \ldots \ldots \ldots \ldots \ldots \ldots \ldots \ldots \ldots \ldots \ldots \ldots \ldots$ Sheaf Oats First Prize - South Carolina, Sheaf Oats

These are the only fairs or shows in which we have exhibited any of our pedigreed seeds
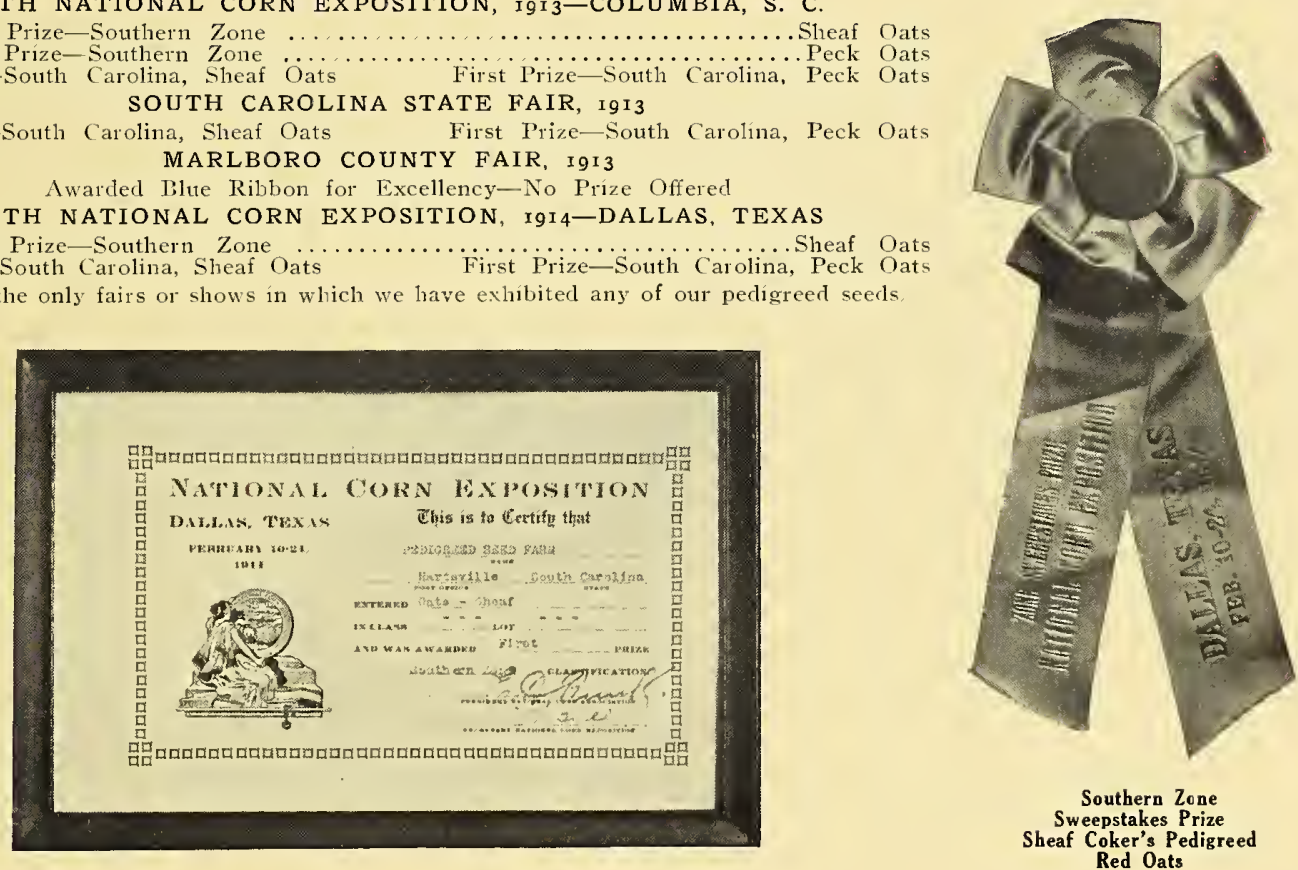

Certificate of Award Southern Zone Sweepstakes Prize Sheaf Coker's Pedigreed Red Oats 


\section{FERTILIZATION OF OATS AND RYE}

The question of WHAT fertilizer to use, and HOW MUCH, is a question that cannot be answered in the same way for every section, as almost every farm requires different amounts and grades of fertilizer, depending upon the soil type, previous treatment, and so on. It would therefore be impossible to give any hard and fast rule for even a small section of the country. For this section, on fairly good soils, of the sandy loam type, we find that an application of two hundred pounds per acre of an 8-4-4 fertilizer when the oats are planted, and one hundred pounds of Nitrate of Soda applied in the spring, give good results. Every farmer however should solve his own fertilizer requirements to suit his soil conditions. The above is what we use, and will be found good on soils similar to ours.

If you are looking for cheap seed, raised by Tom, Dick, and Harry, don't write to us. Every seed we sell is raised under the personal supervision of our plant breeders.
Our "Sign of Quality" is the stamp of approval we give to seed that have made good, and which we stand behind with our reputation as breeders of the best field seed.
"Mr. Coker does not utter advice or proclaim theory until he has first made a comprehensive demonstration of the value of his idea."--Editorial The Country Gentleman, February, I9I4.

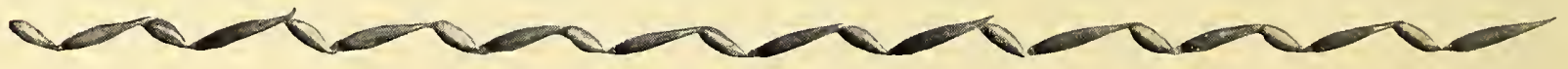




\section{WHY PAY BIG PRICE?}

Why pay us $\$ 1.50$ to $\$ 4.00$ for seeds, when you can buy others at half the price.

Why pay one thousand dollars for a pedigreed trotting stallion, or two hundred dollars for a pedigreed Jersey heifer, or one hundred dollars for a Vanderbilt Berkshire boar, when you can buy a cart horse for one hundred and fifty dollars, a brindled muley cow for forty dollars, or a sandhill rooter for five dollars?

Becattse YOU MUS'T HAVE breeding stock descended from parents of recorded efficiency, both in plants and animals, if you want to raise a high-grade product. PEDIGREED BREEDING STOCK PRODUCES MORE DOLLARS. That's the real reason.

\section{A LETTER FROM MR. W. W. LONG}

PeDigreEd SeEd Farms:

Hartsville, S. C.

Dear Sirs:-As I have frequently said, privately and publicly, I know of no man in the South who in a private way is doing more for its agriculture than $\mathrm{Mr}$. D. R. Coker. He is developing an industry for which there has always been a long-felt need-a seed farm devoted to the interest of pedigreed seed. We always feel absolutely sure when purchasing seed from your farm that it is the purest and that it has been bred with great care and skill. It gives me very great pleastire to recommend to the farmers of not only South Carolina but to the entire South for that matter, any seed offered for sale by Mr. D. R. Coker.

W. W. Long

State Agent and Supt. of Ext., Clemson College, S. C.

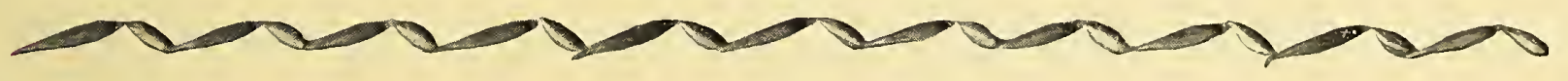




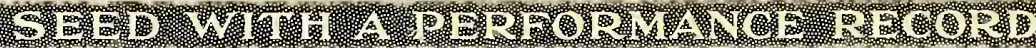

\section{GUARANTEE}

Our seed are bred to Pedigree on our own experiment farms, and we guarantee them to be pure, truc to type, fully matured, and of h:gh germinating power. All seed are handled on our own machines, and are recleaned, graded, and germinated before shipping. While we exercise every precaution to have our seed pure, true, and reliable, we do not give any warranty, expressed or implied, as to yields, and are in no way responsible for the crop: as there are many reasons for crop failures.

Our seed are put up in substantial bags and boxes, and delivered to the railroads in good order. Our responsibility ceases here. When goods arrive in bad order, do not accept then or pay the freight t:ntil your station agent makes out a statement to that effect on your receipted freight bill, which you should hold. You should at once put in claim to the railroal for any loss or damage.

Upon receiving our seed, you have ten days to test them, in any way you may desire. If within that time they are found to be unsatisfactory, in any way, they are to be returned at once in the original packages at our expense, and we will refund your money. We cannot return money for any order that has been ir your hands for more than ten days.

We will entertain no claims for seed which have been planted, for sound seed often fail to germinate under certain conditions.

\section{PRICES}

The prices quted are the only ones at which we will sell these seed to any person or firm. Jobbers and seedsmen must pay the same price as the individual consumer.

\section{Cash must accompany orders.}

Don't place us in the class with ordinary seedsmen. We are Field Seed Specialis's.

Don't fail to examine and test all seed before you plant them. Sometimes good-looking seed have been heated, and won't germinate; sometimes the very best and most vital seed fail to germinate owing to unfavorable weather or soil conditions

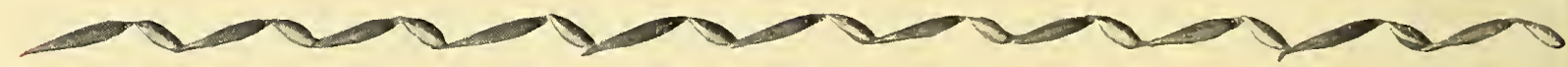




\section{PEDIGREED SEED COMPAN Y OPERATING THE PEDIGREED SEED FARMS}

DAVID R. COKER, Manager

HARTSVILLE, S. C.

\section{ORDER \\ Date}

191

Ship the following seed to:

Name

Mail Address

R. F.D. No.

State

Express or Freight office

Shall we ship by freight, express, or parcel post?

(If by Parcel Post, add amount to cover postage)
AMOUNT ENCLOSED

P. O. Order \$

Express Order $\$$

Check

$\$$

Cash

$\$$

Stamps

$\$$

Total, $\$$

\begin{tabular}{l|l|l|l|l}
\hline \hline NOTE: Cash must accompany orders, as we koop no charge account books. If this is not done, we will have to return your order. \\
\hline \hline QUANTIIY & KIND OF SEED WANTED & - & PRICE \\
\hline$B u$. & Coker's Pedigreed Abruzzi Rye & - & - \\
\hline$B u$. & Coker's Pedigreed Red Oats & - & - \\
\hline
\end{tabular}

PLEASE FILL OUT BACK SIDE OF THIS BLANK

\section{P R I C E S}

Coker's Pedigreed A bruzzi Rye, per Peck, \$1.25: per half-bushel, \$2.25; per bushe1, \$4.00; five per cent. off for ten bushel 1ots and above; ten per cent. off for fifty bushel lots. Coker's Pedigreed Red Oats, per peck, fifty cents; per half-bushel, 85 cents; per bushe!, $\$ 1.50$; five per cent. off for ten bushel lots and above; ten per cent. off for fifty bushel lots. 


\section{PLEASE FILL OUT THE BLANKS BELOW}

Pedigreed Seed Company

Hartsville, S. C.

Dear Sirs:-I think the following planters would appreciate the high-grade seed you are breeding, and I would suggest your sending them circulars and literature.

NAMES

ADDRESS

Signed 


\section{TABLE OF RATES}

\section{A GENERAL IDEA OF TRANSPORTATION CHARGES MAY BE GAINED FROM TABLE BELOW}

\begin{tabular}{|c|c|c|c|c|c|c|c|c|c|c|c|}
\hline \multirow{2}{*}{$\begin{array}{l}\text { RATES } \\
\text { From Hartsville, S. C., to }\end{array}$} & \multirow[b]{2}{*}{$\begin{array}{c}\text { Parcel } \\
\text { Post }\end{array}$} & \multicolumn{2}{|c|}{ EXPRESS } & \multicolumn{2}{|c|}{ FREIGHT } & \multirow{2}{*}{$\begin{array}{l}\text { RATES } \\
\text { From Hartsville, S. C., to }\end{array}$} & \multirow[b]{2}{*}{$\begin{array}{c}\text { Parcel } \\
\text { Post }\end{array}$} & \multicolumn{2}{|c|}{ EXPRESS } & \multicolumn{2}{|c|}{ FREIGHT } \\
\hline & & $\begin{array}{l}\text { Mini- } \\
\text { mum }\end{array}$ & $\begin{array}{r}100 \\
\text { L.bs. } \\
\end{array}$ & $\begin{array}{l}\text { Mini- } \\
\text { mum }\end{array}$ & $\begin{array}{r}100 \\
\mathrm{r}, \mathrm{bs} . \\
\end{array}$ & & & $\begin{array}{l}\text { Mini- } \\
\text { mum }\end{array}$ & $\begin{array}{r}100 \\
\text { I bs. }\end{array}$ & $\begin{array}{l}\text { Mini- } \\
\text { m11m }\end{array}$ & $\begin{array}{l}100 \\
\text { L,bs. }\end{array}$ \\
\hline Bamberg, S. C. .......... & $5-\mathrm{I}$ & 35 & I.IO & 40 & 19.5 & Dillon, S. C. ............ & $5-I$ & 35 & 40 & 25 & I I \\
\hline St. Matthews, S. C. ....... & $5-1$ & 35 & 80 & 40 & 17.6 & Bennettsville, S. C. ......... & $5-1$ & 35 & 40 & 25 & Io \\
\hline Charleston, S. C. .......... & $5^{-I}$ & 35 & 65 & 25 & I4 & Conway, S. C. ........... & $5^{-\mathrm{I}}$ & 35 & 85 & $25^{1}$ & II \\
\hline Columbia, S. C. .......... & $5-I$ & 35 & 60 & 25 & $x_{3}$ & Charlotte, N. C. .......... & $5-I$ & 21 & 64 & $4^{\circ}$ & 20 \\
\hline Edgefield, S. C. .......... & $5-I$ & 35 & 1.00 & 40 & I 9.5 & Fayetteville, N. C. ........ & $5-1$ & $2 I$ & 90 & 25 & 12.5 \\
\hline Anderson, S. C. ......... & $5^{2} \mathrm{I}$ & 35 & I. IO & 40 & 21.6 & Wadesboro, N. C. ......... & $5-1$ & 21 & 49 & 25 & I $3 \cdot 5$ \\
\hline Spartanburg, S. C. ....... & $5^{-1}$ & 35 & 1.00 & 40 & 20.8 & Gibson, N. C. ............ & $5-I$ & $2 \mathrm{I}$ & 45 & 25 & 13.5 \\
\hline Chester, S. C. ........... & $5-1$ & 35 & 80 & 25 & 19 & Augusta, Ga. ............ & $5-1$ & $2 \mathrm{I}$ & 64 & 25 & I 6 \\
\hline Lancaster, S. C. .......... & $5-1$ & 35 & 85 & 25 & 19 & 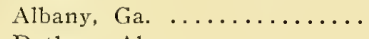 & $6-2$ & 22 & I. 54 & 32 & 32 \\
\hline Camden, S. C. ........... & 5-I & 35 & 60 & 25 & 14.5 & 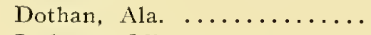 & $7-4$ & 23 & I. 65 & 34 & 34 \\
\hline Cheraw, S. C. ........... & $5-I$ & 35 & 40 & 25 & 9 & Jackson, Miss. $\ldots \ldots \ldots \ldots \ldots$ & $7-4$ & 23 & 2.1 8 & 40 & 40 \\
\hline Florence, S. C. .......... & $5-1$ & 35 & $4^{0}$ & 25 & 9 & Memphis, Tenn. ........... & $7-4$ & 23 & 2.10 & 32 & 32 \\
\hline Marion, S. C. ........... & $5-I$ & 35 & 40 & 25 & Ir & Chattanooga, Tenn. ....... & $6-2$ & 22 & I. 54 & 30 & 30 \\
\hline
\end{tabular}

EXPLANATION OF TABLE: Parcel Post rates above are for the first pound and each additional pound. For example, to a town marked 5 -I, a peck of rye (weight, fourteen pounds), the parcel post charges would be eighteen cents (five cents for first pound, and one cent for each additional pound). In the towns marked 5-I (second prize), it is usually cheaper to ship quantities up to one bushel of oats and one-half bushel of rye by parcel post.

Express rates above are for the minimum rate, and the Ioo- 1 b. rate. For quantities up to IGo lbs, the rate is graduated between these two rates. More than Ioo lbs. are charged for at the hundred-pound rate.

Freight rates are pro rata on the basis of hundredpound rate, with minimum charges as shown above.

WHEN ORDERING TO BE SHIPPED BY PARCEL POST OR PREPAID EXPRESS OR FREIGHT, ADD SUFFICIENT AMOUNT TO COVER CHARGES.

NOTE: RYE WEIGHS FIFTY-SIX POUNDS PER BUSHEL, AND OATS WEIGH THIRTYTWO POUNDS. 


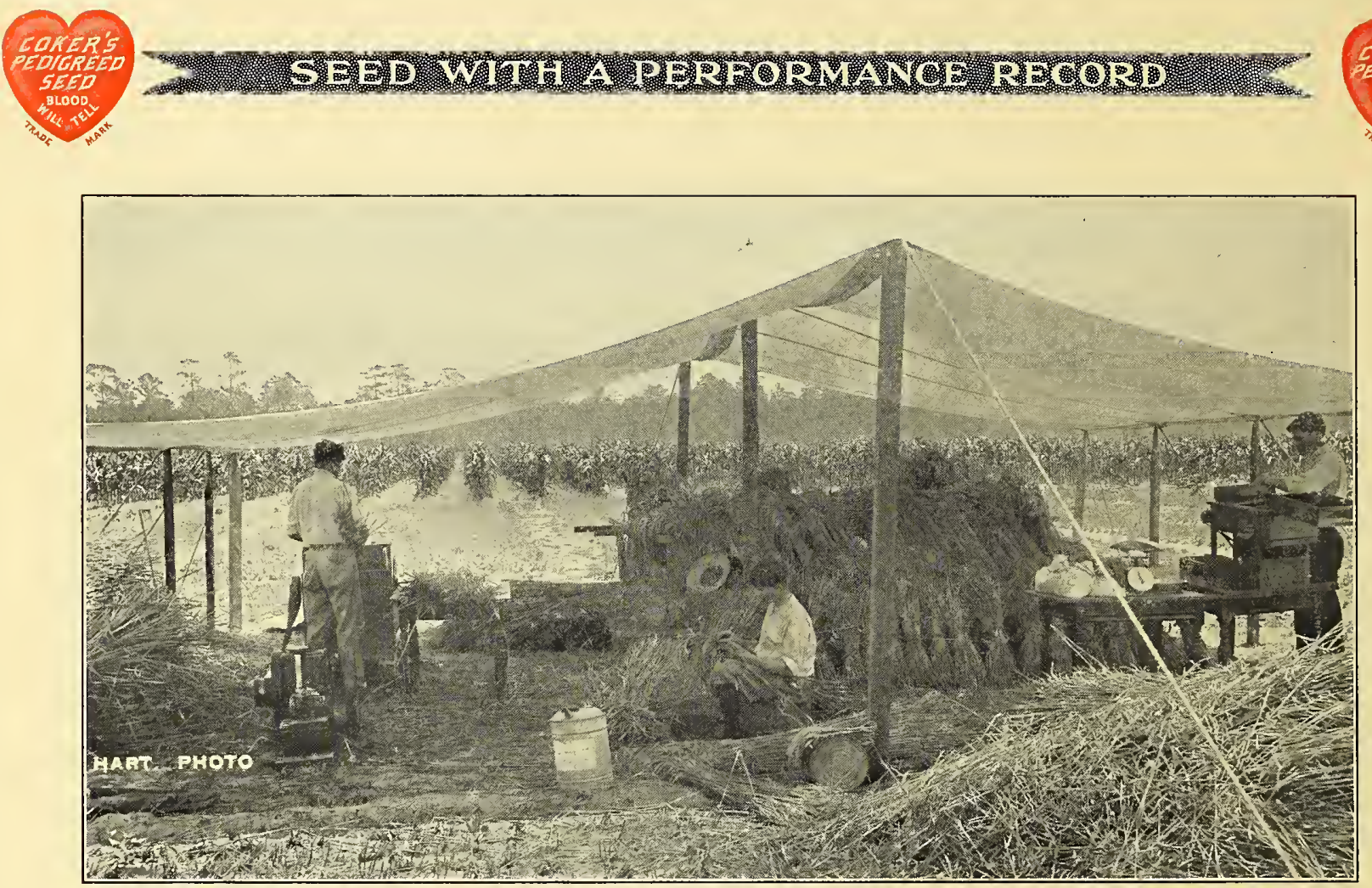

Threshing Oats and Rye Breeding Blocks on Experimental Farm of Pedigreed Seed Company 


\section{OTHER SEEDS}

When you are in need of GOOD FARM SEEDS, seed that are absolutely reliable, seed that have been bred for uniformity and high production, and that have back of them a Pedigree and a HIGH PERFORMANCE RECORD, remember the Pedigreed Seed Company, of Hartsville, S. C. We are FIELD SEED SPECIALISTS, and not general seedsmen. We breed and offer to the farmers of the South the very best possible farm seeds, such seed as will help them to make bigger yields and more money. We offer as Coker's Pedigreed Seed only those seed that have proved themselves superior for at least three years on our seed farms.

Below is a list of the seed we sell. When you need any field seed as listed below, write to us for prices. We are the pioneer FIELD SEED SPECIALISTS of the South.

\section{CORN}

Williamson, Coker's Pedigreed-The most resistant to weevil of any variety we know of.

\section{COTTON, LONG STAPLE}

Webber, Coker's Pedigreed-Harısville, Coker's Pedigreed

PEAS

Iron X Warren New Hybrid, Coker's Pedigreed Whippoorwill X New Era, Coker's Pedigreed

\section{SORGHUM}

Amber, Coker's Pedigreed Sumac, Coker's Pedigreed

\section{BEANS}

Yokohama Velvet Beans, Coker's Pedigreed

We have been breeding some of the above seed for several years, but not until this fall have they been offered to the public. As we perfect their breeding, we are constantly adding to our list seeds of new varieties and crops, but we confine ourselves to FIELD SEEDS exclusively.

REMEMBER, that all our seed are thoroughly recleaned and graded, tested and germinated, before leaving our seed warehouse, and they come to you in our special branded sacks, with a Pedigree and a Guarantee. When buying seed, always look for our TRADE-MARK-"The Sign of Quality."

In addition to the above, we have a small quantity of each of the following seed, which though not bred by us have been tested on our farms and found to be high in yield and true to type.

Marlboro Prolific and Garric Prolific Corn.

Cook's Improved and Mexican Big Boll Cotton.

Keenan-Goodson (long staple) Cotton.

Brabham (wilt resistant) Peas.

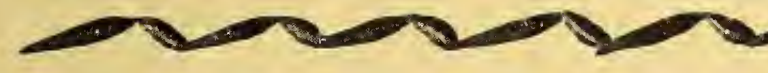




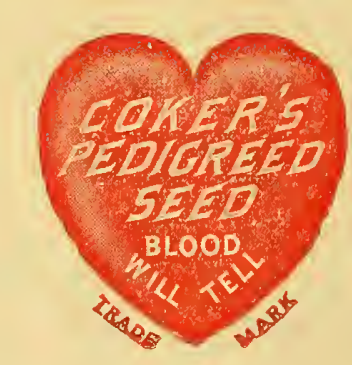

\section{WE ARE FIELD SEED SPECIALISTS-}

NOT GENERAL SEEDSMEN

PEDIGREED SEED COMPANY

HARTSVILLE, S. C. 